Special Issue: Agricultural Productivity and Sustainability Improvement in Tropical Region

\title{
Supplementation of Snakehead Fish Extracts into Tris Egg-Yolk Extender on Mortality and Motility of Limousin Bull Sperm
}

\author{
Haris Setiawan $^{1}$, Aris Winaya ${ }^{1, *}$, Herwintono Herwintono ${ }^{1}$, Mulyoto Pangestu $^{2}$ and Yayuk Kholifah ${ }^{3}$
}

${ }^{1}$ Department of Animal Science, Faculty of Agriculture and Animal Science, University of Muhammadiyah Malang, Jl. Raya Tlogomas 246, Malang 65144, East Java, Indonesia; ${ }^{2}$ Department of Obstetrics and Gynaecology, Faculty of Medicine, Nursing and Health Sciences, Block F, level 5 Monash Medical Centre 246 Clayton Road, Clayton VIC 3168, Monash University, Australia; ${ }^{3}$ Singosari National Artificial Insemination Center, Ministry of Agriculture Republic of Indonesia, Ngujung, Toyomarto, Singosari, Malang, East Java, Indonesia.

Abstract | Freezing process reduces sperm quality due to membrane damage. Antioxidants protects the membrane of spermatozoa. This study aimed to observe the effects of Snakehead Fish (Channa striata [Bloch 1793]) Extract (SFE) supplementation in tris Egg-yolk extender on mortality and motility of spermatozoa of Limousin bull (Bos primigenius f. taurus [Linnaeus, 1758]) collected from Singosari Artificial Insemination Center, Indonesia and commercial SFE. Semen from the same bull were collected and processed according to the protocol at Singosari AI Centre. Semen extender were supplemented with SFE, G0 =0 \% SFE, G1 = $2 \% \mathrm{SFE}, \mathrm{G} 2=4 \% \mathrm{SFE}, \mathrm{G} 3=6 \% \mathrm{SFE}$ and $\mathrm{G} 4=8 \% \mathrm{SFE}$. Each of the treatments was repeated three times. The sperm mortality and motility data from SFE treatments were analyzed using Analysis of Variance (ANOVA). The results showed no significant effect on the mortality and motility of spermatozoa $(P>0.05)$ amongst the treatment. However, there was reduction on mortality and tended to increase on the motility of Limousin bull spermatozoa compared to the non-supplemented extender. Furthermore, the SFE can use in eggyolk extender with some modification for the efficiency of sperm preservation.

Received | January 16, 2021; Accepted | March 12, 2021; Published | May 21, 2021

*Correspondence | Aris Winaya, Department of Animal Science, Faculty of Agriculture and Animal Science, University of Muhammadiyah Malang, Jl. Raya Tlogomas 246, Malang, East Java, Indonesia; Email: winaya@umm.ac.id

Citation | Setiawan, H., A. Winaya, H. Herwintono, M. Pangestu and Y. Kholifah. 2021. Supplementation of snakehead fish extracts into Tris egg-yolk extender on mortality and motility of limousin bull sperm. Sarhad Journal of Agriculture, 37(Special issue 1): 35-40.

DOI | https://dx.doi.org/10.17582/journal.sja/2021/37.s1.35.40

Keywords | Animal breeding, Artificial insemination, Bovine serum albumin, Channalbumin, Cryopreservation.

\section{Introduction}

$\mathrm{T}$ he Indonesian government has declared that Indonesia will reach meat sufficiency in 2026. Increase population through reproduction is the key role. Also reproductive technology needs to be used widely. Consequently, the utilization of frozen semen through artificial insemination is very important. Artificial insemination (AI) is one of the reproductive biotechnologies which has been scientifically proven to improve the genetic quality of livestock (Patel et al., 2017) and most effective tools for improving the productivity of cattle (Thundathil et al., 2016; Ugur et al., 2019). However, the implementation of AI technology relies on sperm quality (Morell et al., 2018). The quality of sperm will reduce gradually during the freezing process, especially in motility and viability (Khalil et al., 2016). The sperm quality maintenance can be done by adding extenders that provides a suitable element to protect spermatozoa 
from freezing stress.

The study by Wahana et al. (2014) showed that the addition of Bovine Serum Albumin (BSA) in phosphate egg-yolk extender significantly increased progressive motility of Turkey's spermatozoa after storage at $4{ }^{\circ} \mathrm{C}$ compare to control. BSA is in liquid phase contains high protein $(5 \mathrm{~g}$ per $500 \mathrm{~mL})$ and 20 different amino acid. BSA also known as extracellular cryo-protectants and supply reserve energy during the semen preservation and cryopreservation.

However, BSA has limited availability since it is imported product, expensive, and difficult to obtain . Albumin protein is also found in some types of fish, although slightly different in structure, such as sharks and stingrays. Albumin in mammal- (HSA and BSA) structures is simple compared to sharks and stingrays, which are more glycoprotein structures (Andreeva, 2010). Asikin and Kusumaningrum (2018) reported that the albumin content of snakehead fish was around $13.95 \%$ to $19.61 \%$. Previous study reported that BSA could be substituted with other compounds, like Snakehead fish (Channa striata Bloch 1793) extract that also rich in minerals, essential and nonessential amino acids that similar to BSA (Chasanah et al., 2015).

This study aimed to observe the supplementation of snakehead fish extract (SFE) into semen extender in the sperm freezing. Evaluation and observation will be made on motility and mortality.

\section{Materials and Methods}

This study was conducted at the National Artificial Insemination Center (BBIB - Balai Besar Inseminasi Buatan) Singosari, Malang, Indonesia. The materials were fresh semen from Limousin bull (Bos primigenius f. taurus [Linnaeus, 1758]), and the commercial product snakehead fish (Channa striata [Bloch 1793]) extract (Pro Albumin(C). The treatments are $\mathrm{G} 0=$ $0 \% \mathrm{SFE}$ (control); G1 = $2 \% \mathrm{SFE}$; G2 = $4 \% \mathrm{SFE}$; $\mathrm{G} 3=6 \% \mathrm{SFE}$ and $\mathrm{G} 4=8 \% \mathrm{SFE}$. Each of SFE (Snakehead Fish Extracts) treatment was repeated three times within the same ejaculate. Macroscopic observations (volume, $\mathrm{pH}$, consistency, color, and smell) were conducted on fresh ejaculate. While microscopic observations (mortality and motility) were-made on fresh ejaculate and after freezing.
Macroscopic observation

The macroscopic observation was applied to spermatozoa before the treatments, including volume, $\mathrm{pH}$, consistency, color, and smell.

\section{Microscopic observation}

\section{Mortality}

The sperm mortality was observed by preparing 100 $\mu \mathrm{L}$ of semen suspension added with $1 \mu \mathrm{L}$ to $2 \mu \mathrm{L}$ drops of eosin $1 \%$ on the object-glass and then mix them. Smear of the suspension was made on an object-glass and dried. Observation was made using a microscope (Olympus, CX 21) with 400× magnification. The spermatozoa that absorbed color indicates that the sperm is dead, while the spermatozoa that did not absorbed color is determined as life sperm (Susilawati, 2011). Percentage of mortality was calculated using the equation (1):

Mortality $(\%)=\left[\frac{\text { number of dead spermatozoa }}{\text { number of counted spermatozoa }}\right] \times 100 \%$......(1)

\section{Motility}

The sperm motility was observed by dripping $10 \mu \mathrm{L}$ of the semen on the object-glass and covered using coverslip. Observation was made under a microscope (Olympus, CX 21) with $400 \times$ magnification at $37^{\circ} \mathrm{C}$. Only spermatozoa with progressively motility were calculated.

\section{Concentration}

The sperm concentration measured using spectrophotometer (Minitube, SDM 5). Fresh semen $(3.5 \mu \mathrm{L})$ was mixed with $3.5 \mathrm{~mL} \mathrm{NaCl} 0.9 \%$ and the suspension was vortexed (Velp Scientifica, Wizaed Advance $1500 \mathrm{~g}$ ) until homogen.

\section{Statistical analysis}

The data were analyzed using Analysis of Variance (ANOVA) and followed by Least Significant Difference (LSD) test if the ANOVA has any significant or very significant effect.

\section{Results and Discussion}

\section{Fresh semen evaluation}

Macroscopic and microscopic assessments of fresh semen were done immediately after collection (Table 1). According to Feradis (2010), the average ejaculate volume of semen bull ranges from $5 \mathrm{~mL}$ to $8 \mathrm{~mL}$. In this study, the Limousin semen ejaculate 
volume was $6.4 \mathrm{~mL}$. This is similar to Mostari et al. (2019) that Limousin breed semen volume around $5.16 \mathrm{~mL}$; Zamuna et al. (2016) was $7.2 \mathrm{~mL}$, and Isnaeni et al. (2019) was $5.48 \mathrm{~mL}$.

Table 1: Fresh semen data from Limousin bull.
Parameter

\section{General condition}

Name

Code

Daren

Type of cow

808101

Age

Weight (kg)

Limousin

11 year old

960

Macroscopic

Color

White

Volume (ml)

$\mathrm{pH}$

6.4

6.8

Consistency

Microscopic

Individual motility ( \%)

54

Mortality (\%)

50

Concentration $\left(10^{6} \mathrm{~mL}^{-1}\right)$
Sperm concentration from fresh ejaculate was 0.538 $\times 10^{6} \mathrm{~mL}^{-1}$, lower than average concentration from other bull. Ma'ruf (2018) reported average of sperm concentration on a 12-year-old of Limousin bull was $0.718 \times 10^{6} \mathrm{~mL}^{-1}$. While Isnaeni et al. (2019) result was $1.2 \times 10^{6} \mathrm{~mL}^{-1}$ and Mostari et al. (2019) was 3.62 $\times 10^{6} \mathrm{~mL}^{-1}$.

The difference quality of the ejaculate are influenced by a different breed of cattle (Rahman et al., 2012), season, breeds, and age or year of semen collection and post thaw sperm quality (D'andre et al., 2017). There is a relationship between sperm concentration and consistency (Sunami et al., 2018).

Motility of Limousin Bull Sperms (\%)

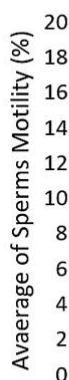

A

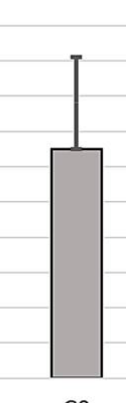

G0

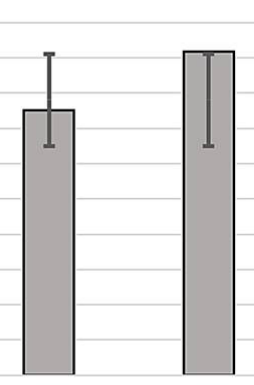

G1
SFE Supplementation

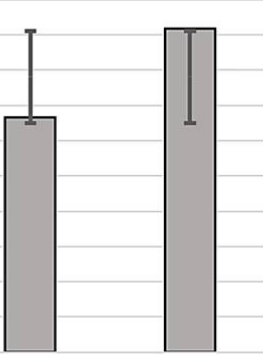

G3

G4
The semen concentration which is measured by using spectrophotometer also can use to calculate the sperm consistency. By using spectrophotometer we can get the information about the data of analysis, sample number, sperm concentration, volume of ejaculate, spermatozoon concentration in a straw, quantity of the necessary extender, and the number of straws received from the semen (Barszcz et al., 2012).

The white color and milky in fresh ejaculate indicated that the sperm has a normal color (Azizunnesa et al., 2013; Jha et al., 2018). Susilawati (2013) stated that the color of normal ejaculate is white or yellowishwhite due to the riboflavin effect. Meanwhile, the reddish-yellow of abnormal sperm caused by the presence of water, pus, and blood.

\section{The mortality of frozen semen}

Figure 1 illustrated the SFE supplementation on semen extender. The highest number of mortality was found in G1 (79.67\%), while the lowest sperm mortality was found in G2 (69\%). The mortality on G3 was higher than G4. The analysis of variance showed no significant effect $(P>0.05)$ on frozen sperm mortality. However, sperm mortality tends to decrease with increasing levels of SFE supplementation (Fig. 1B). This means that the treatment of SFE on extender of frozen semen could reduce the mortality of sperm after thawing.

Freezing process reduces sperm motility. It has been known that the freezing process changes the structure and function of spermatozoa due to membrane protein denaturation, shrinkage, and irreversible membrane collapse (Khalil et al., 2018). Therefore, managing the phospholipid and cryoprotective agents, as well as optimal dilution rate, equilibration, and cooling procedures, can avoid cold shock, reduce ice crystal

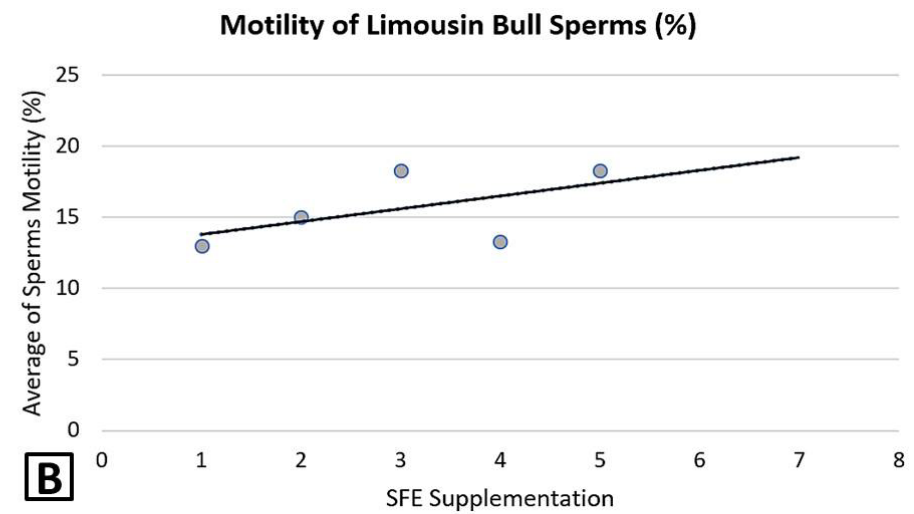

Figure 1: The effect of SFE supplementation with different levels on the mortality of spermatozoa. A, The spermatozoa mortality of frozen semen on post thawing. $B$, The trend of sperm mortality on post thawing test. 

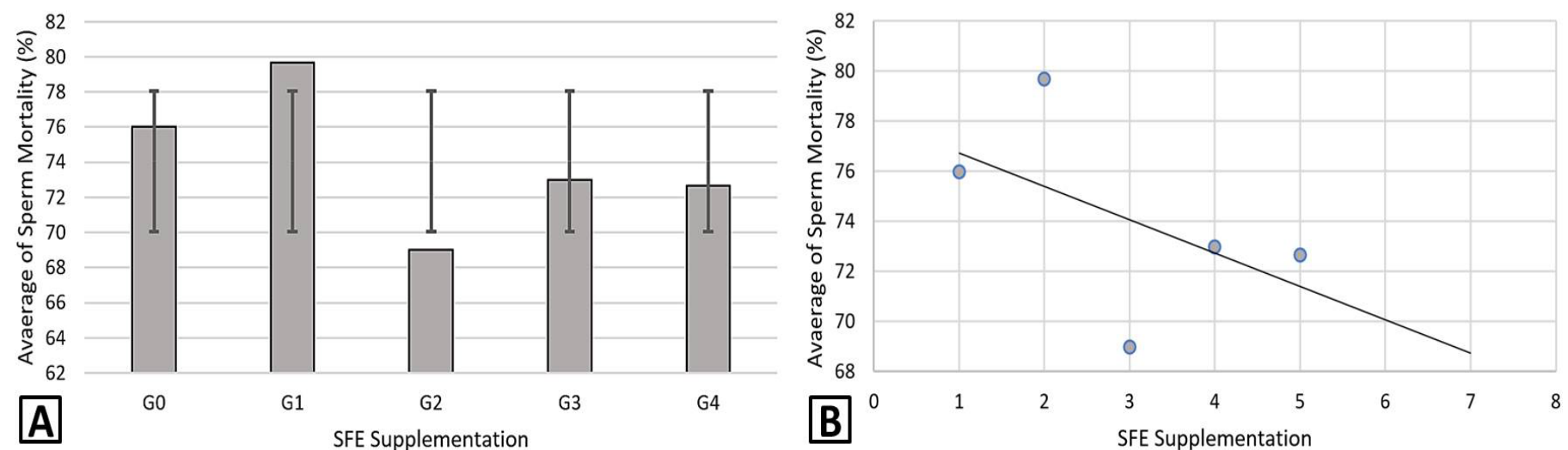

A SFE Supplementation

Figure 2: Illustrated data of frozen semen motility after supplemented by SFE. A, The spermatozoa motility of frozen semen on post thawing. B, The trend of sperm motility on post thawing test.

formation, and minimize sperm damage. Supplementation of SFE extract as an alternative protein sources in semen extender may not optimal in protecting the sperm plasma membrane during cryopreservation. Heating process during the SFE production, may damage the albumin and amino acid content and reduces its protecting ability. Protein denatures at $50{ }^{\circ} \mathrm{C}$ to $60{ }^{\circ} \mathrm{C}$ and $10{ }^{\circ} \mathrm{C}$ to $15^{\circ} \mathrm{C}$. The denaturation process does not damage the peptide bond in the primary structure but changes its folding shape (Kunsah, 2016).

\section{The motility offrozen semen}

The effect of SFE supplementation into the sperm motility after thawing was shown in Figure 2. In G0 treatment, sperm motility was $13.33 \%$ and increased to $15 \%$ at G1 treatment. It was then followed by G2 treatment which reach the peaks at $18.33 \%$. It decreased to $13.33 \%$ in G3 treatment before then increased again to $18.33 \%$ in G4 treatment. Sperm motility after thawing semen was fluctuated (Fig. 2A), but based on data trend analysis, it showed any incremental trend up to $8 \%$ (Fig. 2B).

Table 2: Analysis of variance.

\begin{tabular}{lccccc} 
Source & $\begin{array}{l}\text { Sum of } \\
\text { squares }\end{array}$ & df & $\begin{array}{c}\text { Mean } \\
\text { square }\end{array}$ & F & Sig. \\
Between groups & 191.600 & 4 & 47.900 & 1.126 & 0.398 \\
Within groups & 425.333 & 10 & 42.533 & & \\
Total & 616.933 & 14 & & & \\
\hline
\end{tabular}

Sig. >0.05 SFE treatments had no signification effect.

The mortality and motility of semen were observed after fresh Limousin semen treated with SFE supplementation and stored in deep freeze by $-180{ }^{\circ} \mathrm{C}$ as long as $24 \mathrm{~h}$.
The data of the frozen-thawed sperm after treatments is shown in Table 4. The statistical analysis showed that supplementation of SFE in tris egg-yolk extender has no significant effect $(\mathrm{P}>0.05)$ to sperm motility after thawing (Table 5). However, there was a tendency of increasing motility compared to the control (nonsupplemented extender). SFE supplementation up to $8 \%$ was not enough to influence the motility and mortality of frozen sperm after thawing. One of the factors that can reduce motility, viability, and morphological damage in sperm after freezing is reactive oxygen species (ROS) (Wagner et al., 2017). Addition anti-oxidant reduces the ROS reaction. SFE contains antioxidant but it was not enough to influence the motility and mortality of sperm at a significant level.

Table 4: The motility of frozen-thawed sperm after treatments

$\begin{array}{ll}\text { Treatments } & \text { Motility (\%) } \\ \text { G0 } & 13.33 \pm 5.77 \\ \text { G1 } & 15.00 \pm 5.00 \\ \text { G2 } & 18.33 \pm 5.77 \\ \text { G3 } & 13.33 \pm 2.88 \\ \text { G4 } & 18.33 \pm 2.88\end{array}$

Notes: $G 0=0 \% S F E$ (control); $G 1=2 \% S F E ; G 2=4 \% S F E$; $G 3=6 \% S F E$ and $G 4=8 \% S F E$

Table 5: Analysis of variance of the sperm motility after thawing

\begin{tabular}{|llllll|}
\hline Source & $\begin{array}{l}\text { Sum of } \\
\text { squares }\end{array}$ & df & $\begin{array}{l}\text { Mean } \\
\text { square }\end{array}$ & F & Sig. \\
\hline Between groups & 76.667 & 4 & 19.167 & $0.885^{\text {ns }}$ & 0.507 \\
Within groups & 216.667 & 10 & 21.667 & & \\
\hline Total & 293.333 & 14 & & & \\
\hline
\end{tabular}

Note: $n s=$ not significant

The albumin content of SFE may not provide 
sufficient nutrition and give protection of the sperm membrane during cryo-preservation processes. Widodo (2016) stated that protein could be broken down into amino acids by releasing its amino groups through deaminase oxidative or pyruvate and acetyl coenzyme-A formed before entering Crab's cycle to form energy. Amino acids, such as alanine, cysteine, glycine, threonine, serine, and hydroxyproline, are converted into pyruvate. All amino acids that made to pyruvate can be converted to acetyl coenzyme-A, except five amino acids without through pyruvate forms, namely phenylalanine, tyrosine, tryptophan, lysine, and leucine. These amino acids are not directly utilized by spermatozoa for motility due to its longchain-break down. The variation of sperm motility might due to age, breed of bull, inadequate nutrition, and poor management (Akhter et al., 2013).

\section{Conclusions and Recommendations}

Supplementation of snakehead fish extract (SFE) until $8 \%$ into tris egg yolk extender was not a significant effect on mortality and motility of Limousin bull semen after thawing of stored semen. However, the data analysis showed mortality reduction and an motility improvement. This means that the SFE can use as an alternative for protein source for cryopreserved bull semen with corresponding to substitute BSA protein

\section{Acknowledgements}

The authors would like to thanks the Rector of University of Muhammadiyah Malang that gave the opportunity to conduct this research successfully. Extended thank is to the Head of National Artificial Insemination Center (BBIB - Balai Besar Iseminasi Buatan), Ministry of Agriculture, the Republic of Indonesia for the permission of conducting the experiment and use laboratory facilities for spermatozoa assessments.

\section{Novelty Statement}

The use of Snakehead fish (Channa striata, [Bloch 1793]) extract as an extender in the frozen semen is still not revealed until recently, especially on Limousin bull (Bos primigenius f. taurus [Linnaeus, 1758]) semen. Thus, this initial study could be as an important information related to the potency of Snakehead fish extract as an alternative substitution of
Bovine Serum Albumin (BSA) for extender dilution in freezing semen processes.

\section{Author's Contribution}

HS and AW conceived and designed the study, carried out definition of intellectual content, performed literature search, experimental studies, data acquisition, data analysis, statistical analysis, and manucript preparation. $\mathrm{HH}, \mathrm{MP}$ and YK elaborated intellectual content, performed literature search, experimental studies, and manuscript editing and review. AW and MP perfomed guarantor. All authors read and approved the final manuscript.

\section{Conflict of interest}

The authors declares that there is no conflict of interests regarding the publication of this article.

\section{References}

Akhter, M.S., M.A.K. Azad, M.Z. Rahman and A. Ashraf, A. 2013. Study on the quality of semen of different genetic groups of bull from Khulna Region of Bangladesh. Int. J. Pharm. Biomed. Res., 1: 19-23.

Andreeva, A.M. 2010. Structure of fish serum albumins. J. Evol. Biochem. Physiol., 46: 135-144. https://doi.org/10.1134/ S0022093010020018

Asikin, A.N. and I. Kusumaningrum. 2018. Albumin profile of snakehead fish (Channa striata) from East Kalimantan, Indonesia. IOP Conf. Ser.Earth Environ. Sci., 144:1-5. https:// doi.org/10.1088/1755-1315/144/1/012035

Azizunnesa, B., F. Zohara, F.Y. Bari and M.G.S. Alam. 2013. Effects of concentrate supplementation on reproductive performances and semen quality of indigenous rams in Bangladesh. J. Embryo Trans., 28: 325-335. https://doi.org/10.12750/JET.2013.28.4.325

Barszcz, K., D. Wiesetek, M. Wąsowicz and M. Kupczyńska. 2012. Bull semen collection and analysis for artificial insemination. J. Agric. Sci., 4: 1-10. https://doi.org/10.5539/jas.v4n3p1

Chasanah, E., M. Nurimala, A.R. Purnamasari and D. Fitriani. 2015. Chemical composition, albumin content and bioactivity of crude protein extract of native and cultured of Channa striata fish. J. Pascapanen Bioteknol. 
Kelautan Perikanan, 10: 123-132. https://doi. org/10.15578/jpbkp.v10i2.364

D'Andre, H.C., K.D. Rugira, A. Elyse, I. Claire, N. Vincent, M. Celestin, M. Maximillian, M. Tiba, N. Pascal, N.A. Marie, K. Christine and G. Daphrose. 2017. Influence of breed, season and age on quality bovine semen used for artificial insemination. Int. J. Livest. Prod., 8: 72-78. https://doi.org/10.5897/IJLP2017.0368

Feradis. 2010. Reproductive biotechnology on livestock. Penerbit Alfabveta, Bandung, Indonesia.

Jha, P.K., G.S. Alam, A. Al Mansur, T. Islam and F.Y. Bari. 2018. Selection of breeding rams by evaluating semen quality. J. Appl. Anim. Sci., 11: 9-20.

Isnaini, N., S. Wahjuningsih, A. Ma'ruf and D.A. Witayanto. 2019. Effects of age and breed on semen quality of beef bull sires in an Indonesian artificial insemination center. Livest. Res. Rural. Dev., 31: Article 78.

Khalil, W.A., M.A. El-Harairy, A.E.B. Zeidan, M.A.E. Hassan and O. Mohey-Elsaeed. 2018. Evaluation of bull spermatozoa during and after cryopreservation: Structural and ultrastructural insights. Int. J. Vet. Sci. Med., 6: S49-S56. https://doi.org/10.1016/j.ijvsm.2017.11.001

Kunsah, B. 2016. Protein analysis of Gallus domesticus egg storage at temperature 12 to 15 ${ }^{\circ} \mathrm{C}$. J. Muhammadiyah Med. Lab. Technol., 2: 54-63.

Ma'ruf, A. 2018. The comparison of fresh semen quality and quantity and recovery rate from Limousin and Bali Bull. Thesis, Brawijaya University, Malang.

Morrell, J.M., A.S. Valeanu, N. Lundeheim and A. Johannisson. 2018. Sperm quality in frozen beef and dairy bull semen. Acta Vet. Scand., 60: s13028. https://doi.org/10.1186/s13028-0180396-2

Mostari, M.P., M.S. Islam, M.Y.A. Khan and M. Morshed, M. 2019. Evaluation of different crossbreed Beef Bulls based on physical and bio-chemical properties of semen at BLRI cattle research farm. IOSR J. Agric. Vet. Sci., 12: 59-71.

Patel, G.K., N. Haque, M. Madhavatar, A.K. Chaudhari, D.K. Patel, N. Bhalakiya, N.
Jamnesha,P.Patel and R. Kumar.2017.Artificial insemination: A tool to improve livestock productivity. J. Pharmacogn. Phytochem., 1: 307-313.

Rahman, M.A., N.S. Juyena, J.U. Ahmed, R.N. Ferdousy, S. Chakma, M.Z. Rine and A.M.M. Tarif. 2014. Evaluation of semen for breeding soundness of four different breeds of bull used for artificial insemination. IOSR J. Agric. Vet. Sci., 7: 28-34. https://doi.org/10.9790/238007922834

Sunami, S., N. Isnaini, and S. Wahjuningsih. 2017. Fresh semen quality and recovery rate of Limousin cow in different season. J. Ternak Tropika, 18: 36-50. https://doi.org/10.21776/ ub.jtapro.2017.018.01.6

Susilawati, T. 2011. Spermatology. Universitas Brawijaya Press, Malang, Indonesia.

Susilawati, T. 2013. Artificial insemination guideline on livestock. Universitas Brawijaya Press, Malang, Indonesia.

Thundathil, J.C., A.L. Dance and J.P. Kastelic. 2016. Fertility management of bulls to improve beef cattle productivity. Theriogenology, 86: 397-405. https://doi.org/10.1016/j. theriogenology.2016.04.054

Ugur, M.R., A.S. Abdelrahman, H.C. Evans, A.A. Gilmore, M. Hitit, R.I. Arif, B. Purwantara, A. Kaya and E. Memili, E. 2019. Advances in cryopreservation of bull sperm.Front. Vet. Sci.,6: 268. https://doi.org/10.3389/fvets.2019.00268

Wagner, H., J.W. Cheng and Y.K. Edmund. 2017. Role of reactive oxygen species in male infertility: An updated review of literature. Arab J. Urol., 16: 35-43. https://doi.org/10.1016/j. aju.2017.11.001

Wahana, A.G., M.K. Budiasa and Bebas, W. 2014. The addition of bovine serum albumin to maintain progressive motility of Turkeys spermatozoa storage at temperature $4{ }^{\circ} \mathrm{C}$. Indonesia Med. Vet., 3: 317-322.

Widodo, W. 2016. Poultry nutrition science. Universitas Muhammadiyah Malang Press, Malang, Indonesia.

Zamuna, A.A.K.M., T. Susilawati and G. Ciptadi 2016. Evaluation of different breeds of beef cattle bull's capacity in producing frozen sperms. Res. Zool., 6: 8-10. 